\title{
Enajsta konferenca Komisije za slovansko besedotvorje pri Mednarodnem slavističnem komiteju
}

\author{
Irena Stramljič Breznik
}

\begin{abstract}
Enajsto zasedanje Komisije za slovansko besedotvorje je tokrat potekalo od 24. do 26. marca 2009 v Moskvi na temo Novi pojavi v slovanskem besedotvorju: sistem in delovanje, kar je bil eden izmed dvanajstih vsebinskih sklopov na mednarodnem znanstvenem simpoziju z naslovom Slovanski jeziki in kulture v sodobnem svetu; udeležilo se ga je okrog petsto slavistov s celega sveta.

\section{The 11th Conference of the Slavic Word-Formation Committee of the International Committee of Slavists}

The eleventh session of the Slavic Word-Formation Committee took place from 24 to 26 March 2009 in Moscow with the theme New Phenomena in Slavic Word Formation: System and Function (Новые явления в славянском словообразовании: система и функиионирование). This was one of twelve thematic groups at the international scholarly symposium titled Slavic Languages and Cultures in Today's World (Славянские языки и культуры в современном мире), in which approximately five hundred Slavic specialists from around the world participated.
\end{abstract}

Kot je razvidno iz zgodovine Komisije za slovansko besedotvorje (http://www. komisja_slowotworcza_mks.ap.siedlce.pl/), je bila ustanovljena na plenarnem zasedanju Mednarodnega slavističnega komiteja leta 1994, naslednjega leta pa tudi potrjena pod vodstvom Igorja Uluhanova. Ta jo je vodil v letih 1995-2006 (Volgograd 1996, Magdeburg 1997, Innsbruck 1999, Katovice 2000, Wittenberg 2001, Minsk 2003, Bratislava 2004, Berlin 2005, Minsk 2006), v Sofiji 2007 pa je vodenje komisije prevzel Aleksander Lukašanec, ki je tudi eden redkih udeležencev vseh znanstvenih srečanj.

Pod odličnim vodstvom organizatorice Jelene Petruhine (Moskva) se je simpozij komisije pričel $\mathrm{v}$ poznih popoldanskih urah 24. marca $\mathrm{z}$ okroglo mizo o temeljnih diskusijskih vprašanjih slovanskega besedotvorja in nominacije glede na razmerje med domačim in prevzetim ter med ustaljeno rabo in besedotvornim sistemom.

I. Ohnheiser (Avstrija) je kot prva diskutantka ob gradivu slovarja neologizmov ruskega in poljskega jezika razmišljala o tem, ali se danes spreminjajo razmerja med tradicionalnimi funkcijami besedotvorja. Semantično-funkcijska diferenciacija jezikovnih virov glede na domače in prevzeto je k razmisleku spodbudila J. A. Karpilovsko (Ukrajina), Jelena Petruhina je predstavila možnosti, funkcije in 
konkurenčnost tvorjenja besed $\mathrm{v}$ sodobnem ruskem jeziku, ki jih je s predstavitvijo igrivih mehanizmov tvorjenja žargonizmov dopolnil M. A. Kronhaus (Rusija).

Naslednjega dne so se člani komisije zvrstili v dopoldanski sekciji Novi pojavi $v$ slovanskem besedotvorju z vidika besedotovorne teorije. Po pozdravnem nagovoru predsednika A. A. Lukašanca (Belorusija) je čast uvodnega referenta pripadala dolgoletnemu predsedniku I. S. Uluhanovu (Rusija), ki je prikazal uresničevanje sistemskih zakonitosti jezika v novi ruski leksiki, J. S. Kubrjakova (Rusija) pa se je posvetila analogiji pri nastajanju novih besed. Jezikovni purizem kot dejavnik razvoja besedotvornega sistema na beloruskem gradivu tvorjenk je bila osrednja tema prispevka A. A. Lukašanca, medtem ko je G. P. Neščimenko (Rusija) predstavila težnjo jezikovne ekonomije kot dejavnik razvoja knjižnih norm v slovanskih jezikih. Zanimivo je besedotvorje povezala s teorijo semiotike A. Nagorko (Nemčija), saj je predstavila zvezo med ikoničnostjo in besedotvorno motivacijo. Besedotvorna sredstva intelektualizacije $\mathrm{v}$ sodobnem ukrajinskem jeziku so bila $\mathrm{v}$ središču zanimanja N. F. Klimenko (Ukrajina). J. Baltova (Bolgarija) je predstavila zelo zanimiv pregled različne besedotvorne in leksikalne interpretacije enakih internacionanih morfemov v slovanskih jezikih (npr. super-, kontra- v nekaterih jezikih uvrščajo med predponske morfeme, drugod med sestavine zloženk). O. P. Jermakova (Rusija) je predstavila težave pri raziskovanju tvorbeno vezanih korenskih pomenov v sodobnem besedotvorju. Kot priznana strokovnjakina za vprašanja internacionalizacijskih pojavov $\mathrm{v}$ besedotvorju poljskega jezika je K. Waszakowa (Poljska) s stališča kognitivne semantike predstavila pogled na tvorbene inovacije, ki so rezultat zlitja pomenov. R. Dragićević (Srbija) je predstavila nadvse zanimiv besednodružinski slovar srbskega jezika v dveh knjigah, ki je hkrati še tematski, saj predstavlja zunanje in notranje dele človeškega telesa kot tudi tipične psihofiziološke in psihofizične lastnosti človeka. Na divergentne procese $\mathrm{v}$ sodobnem besedotvorju srbskega, hrvaškega in bosanskega jezika je opozoril B. Tošović (Avstrija), I. Stramljič Breznik (Slovenija) pa na besedotvorne posebnosti slovenskih priložnostnic, ki jih sproža nova, izvirna morfemska kombinatorika jeziku lastnih ali pa v njem že ustaljenih in prilagojenih prevzetih prvin, ter tako opozorila, da je slovenski jezik sposoben črpati regenerativno moč iz lastnih, ne samo internacionalnih tvorbenih prvin in vzorcev.

Popoldansko zasedanje je bilo namenjeno Tipologiji novih pojavov in težnjam $v$ spremembah slovanskega besedotvorja. Glavnina prispevkov se je ukvarjala z vprašanjem aktivnih besedotvornih procesov $\mathrm{v}$ slovanskih jezikih posamezno ali pa protistavno, npr. za ruščino in poljščino (E. A. Zemska in Z. Rudnik-Karpatova), pregled inovacij v tvorjenju besed s pomenom nomina abstrakta $\mathrm{v}$ ruščini, poljščini in nemščini je lepo predstavila E. Koriakowcewa (Poljska), zanimiv pa je bil razmislek K. Kleszczowe (Poljska) o mestu napak in inovacij v dinamiki jezikovnega razvoja. Kolegici iz Bolgarije sta prispevali tipološki pogled na nove pojave v slovanskih jezikih (C. Avramova) in vpliv tujejezične leksike nanje (V. Radeva). Internacionalizacijske težnje v češčini je predstavila I. Bozděchová, inovacije v slovaščini s slovničnega, strukturnega in pragmatičnega vidika pa N. Janočkova (Slovaška). S stališča homonimije je o univerbizaciji v srbščini spregovoril B. Ćorić (Srbija). Vprašanju paradigmatskih razmerij glagolov s predpono $o b$ - in njihovemu 
prikazu v slovarju je pozornost namenila R. Belentschikow (Nemčija), na dejavnik inovacij, ki nastajajo pri tvorjenju besed v umetnostnih besedilih, pa je opozorila V. N. Vinogradova (Rusija).

$\mathrm{V}$ tretji sekciji, ki ji je bil namenjen tematski sklop Besedotvorje v podsistemih slovanskih jezikov, je 26. marca nastopilo veliko zanimivih referentov, ki so razmišljali o jezikovnih spremembah $z$ vidika socialno-kulturnega šoka ter o t. i. potencialnih besedah in akronimih na spletu. V. V. Himik (Rusija) je podrobneje analiziral pomen, sistemskost in vlogo ruskih manjšalnic. L. A. Arajeva (Rusija) se je na primeru imen podjetij in trgovin spraševala, ali je besedotvorje 21. stoletja kaotično ali gre za eksplozijo asociacij na podlagi stereotipov. Podobno zanimivega področja se je dotaknila še T. V. Popova (Rusija), ki je opozorila na nove besedotvorne formante $\mathrm{v}$ grafoderivatih. Kot člani Komisije za slovansko besedotvorje so bili najavljeni trije referenti, izmed katerih pa J. Raecke (Nemčija) ni nastopil. J. Sierociuk (Poljska) je predstavil besedotvorje govorjenega jezika na primeru narečij in E. G. Lukašanec (Belorusija) na ruskem argoju kriminalnih združb sistemskost sociolektalnega besedotvorja.

Na simpoziju v Moskvi 2009 je bilo na zasedanju Komisije sklenjeno, da bo dvanajsto znanstveno srečanje slovanskih besedotvorcev na temo Odsev zgodovine in kulture naroda v besedotvorju v Kijevu od 24. do 27. maja 2010, glavna organizatorica srečanja pa bo Jevgenija Karpilovska z Inštituta za jezikoslovje pri Ukrajinski akademiji znanosti.

O mednarodnem znanstvenem simpoziju Slovanski jeziki in kulture v sodobnem svetu je tako glede števila udeležencev, tematskih sklopov kot tudi po zanimivih prispevkih mogoče govoriti v presežnikih. Omeniti velja, da smo se ga v lepem številu udeležili tudi slavisti vseh treh slovenskih univerz (Aleksandra Derganc, Aleksander Skaza, Andrej Rozman, Maria Wtorkowska, Petra Stankovska, Krištof Jacek Kozak, Tomo Virk in Irena Stramljič Breznik), ki smo se razpršili po različnih sekcijah, katerih delo se je prekrivalo, zato so daljši povzetki vseh nastopajočih zbrani v obsežnem zborniku na 450 straneh. 